\title{
9
}

\section{Pursuing the Antipodean: Bernard Smith, Identity and History}

\section{Sheridan Palmer}

Identity mattered to Bernard Smith, probably more than for most people. As an illegitimate child and a fostered ward of the state, anonymity had haunted him, but it also drove his ambitions. By using these two opposing structures as tension rods, identity and anonymity, he sought validation through his work and recognition as an art and cultural historian. His revision of Australia's modern cultural evolution, written from a fiercely independent position, was based around colonial inheritance, cultural traffic and transformation, but it was also intended to shake up an 'uncritical culture' and situate it in a more conspicuous international position. From the mid-1940s, his historiography became the benchmark for scholars and artists in their pursuit of, or argument with, Antipodean identity and cultural autonomy, and this chapter seeks to explain why Bernard Smith's rethinking of antipodeanism - a term he coined - and his aim to legitimate Australian culture within a globalised postwar world was a pioneering and brilliant study of cultural origins and evolution; at a personal level it reflected his own genesis. 


\section{'To understand Australia one must look elsewhere"1}

Writing to his friend Lindsay Gordon in 1948, Bernard Smith stated:

I am becoming convinced that the conceptions of ... Utopia, and 'working man's paradise' in the Southern Land is one of the central historical ideas running through Australian literature, art and politics. It is perhaps the myth-making of the voyager and the emigrant ... another aspect of Illusion and Reality. ${ }^{2}$

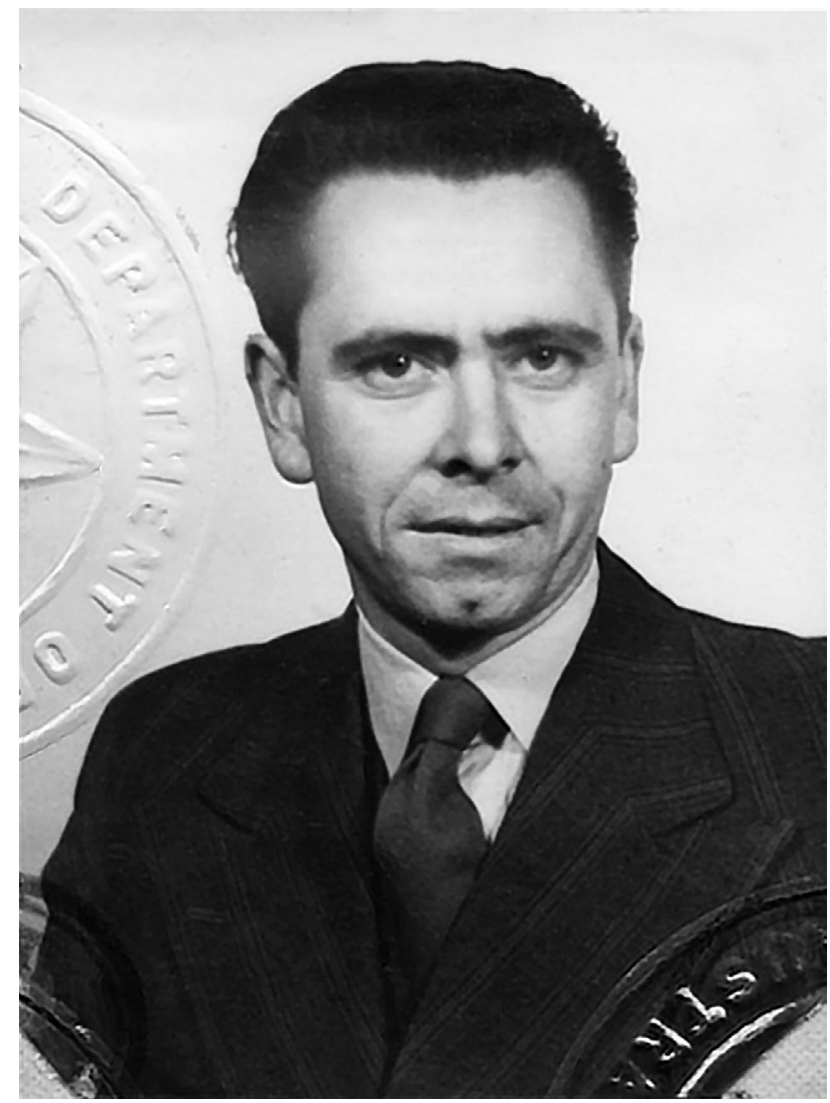

Bernard Smith, 1948 passport photo

Source: Bernard Smith Papers, National Library of Australia.

1 Noel McLachlan, 'Godzone: The Australian Intellectual', Meanjin (Melbourne), 26:1 (1967), 6. 2 Bernard Smith to Lindsay Gordon, 23 November 1948, Bernard Smith Papers, National Library of Australia (hereafter NLA), Acc. 10.088, Box 19. 
At the time, Smith was one of Australia's up-and-coming young intellectuals and had arrived in London on a British Council scholarship to study at the Courtauld Institute of Art.

His research project was a comparative survey of the origins of Australian art with that of British painting and architecture between 1788 and 1835, and to consider in greater detail the impact of the British on the South Pacific. He had already commenced this with his acclaimed analysis of Australia's sociocultural evolution from colonial settlement to 1945 in his first book, Place, Taste and Tradition: A Study of Australian Art since 1788. His area of research, however, was a relatively new field of enquiry, especially the impact of British imperialism in the Pacific and colonial settlement in the Antipodes, but his academic approach to the subject would prove significant on several counts. First, his meticulously incisive, polemical nature would evaluate British material from an Australian perspective, and second, he possessed an acute sense of identity as an outsider.

On his first meeting with Anthony Blunt, the director of the Courtauld Institute, Smith was taken aback by the Englishman's cultural superiority, conspicuous class-consciousness and the inference that Australia was subcultural; a hangover, he assumed, of a postcolonial mentality. Later, he discovered a letter that Blunt had written to John Summerson, the director of the Sir John Soane Museum at Lincoln Inn Fields, which proved his reaction had not been unfounded: 'This is to introduce Mr Bernard Smith from Australia, who has been hitherto working on the early phase of painting in and of Australia with remarkable results (contrary to the expectations aroused by the subject). ${ }^{3}$ What Smith did not know was that Blunt's private life was in complete turmoil and his 'chilling elegance' a mask for his personal and political alienation. ${ }^{4}$ Nevertheless, Blunt's condescending and patronising manner made him feel like a 'mere colonial, a modern Antipodean' and it reinforced his perception that England was a self-absorbed nation. Historian Perry Anderson has defined this as a country that possesses a cultural tradition with an 'absent centre'. England, he wrote, 'may be defined as the European country which - uniquely - never produced either classical sociology or

3 Anthony Blunt to John Summerson, 19 October 1949 (copy), Bernard Smith Papers, NLA, MS 8680, Acc. 10.088, Box 33.

4 Smith later claimed that Blunt may have known about his communist affiliation and that MI5 were monitoring his movements and, given Blunt's undercover activity as a spy, it is understandable he would have been nervous about Smith's presence. 
national Marxism ... [It] was never challenged as a whole from within'. In this context, Bernard Smith would use his encounter with Blunt and other elitist Englishmen as a tuning fork to understand British hegemony both in its historical and modern form. Moreover, Smith's encounter with Blunt made him look at himself and what it meant to be Antipodean in the world, and to resituate it politically, culturally and globally.

Fortunately for Bernard Smith, Anthony Blunt moved him from the Courtauld Institute to that 'republic of learning' the Warburg Institute, where he studied under some of Europe's most brilliant scholars, most of whom were exiled from Hitler's Germany. ${ }^{6}$ Under their guidance, he delved deep into British archives and libraries looking at some of the earliest material on the southern hemisphere and how Terra Australis Incognita had first been perceived - what he described as the upsidedown long view of historical reconstruction. Smith also realised how profoundly the mythological memory had permeated history, and was reminded of his friend Lindsay Gordon's parting words: 'Somewhere in the primitive deep of the mind and the ritual of fare-welling ships there is something of [the] birth image mixed up with the hint of Styx. ${ }^{7}$ Myths, symbols and utopian or renewal concepts had imaginatively interlaced history since ancient time, and the publication of mappa mundi, especially from the early sixteenth and seventeenth centuries, was integral to the perception of Terra incognita. ${ }^{8}$ Francis Bacon's New Atlantis, published in 1627, was an imaginative construction and a travel fantasy concerning a new utopia in the Pacific Ocean, which influenced thinkers such as the French Encyclopaedists, Immanuel Kant and Karl Marx as a model for renovating scientific, moral and social laws. ${ }^{9}$ Indeed, Bacon's fictional 'Salomon House' became an institutional model for the Royal Society founded in 1660, which in turn influenced numerous other academies. ${ }^{10}$

5 Perry Anderson, quoted in Lesley Johnson, The Cultural Critics: From Matthew Arnold to Raymond Williams (London: Routledge \& Kegan Paul, 1972), 12.

6 Blunt told Bernard that he could not read an Honours course at the Courtauld Institute as he had not completed an undergraduate degree nor was his subject compatible to the Courtauld Institute's research program.

7 Lindsay Gordon to Bernard Smith, 7 September 1948, Bernard Smith Papers, NLA, Acc. 10.088, Box 19 .

8 See Bronwen Douglas, 'Terra Australis to Oceania: Racial Geography in the "Fifth Part of the World", Journal of Pacific History, 45:2 (2010), 179-210, doi.org/10.1080/00223344.2010.501696.

9 Bronwen Price, ed., Francis Bacon's New Atlantis: New Interdisciplinary Essays (Manchester/New York: Manchester University Press, 2002), 14-16.

10 Ibid., 15. 
Other sources included Robert Burton's 'ideal kingdom': 'it may be in Terra Australis Incognita ... perhaps under the Equator, that paradise of the world ... the longitude for some reason I will conceal'. ${ }^{11}$

But it was perhaps Linnaeus's system of identification and classification that had significant implications for the New World. In a recent study of race and nationalism David Bindman noted that:

Linnaeus offered a classification of humanity, based upon the Four Continents or Four Quarters of the Earth and the Four Temperaments associated with each ... add[ing] a number of other categories, including the Wild Man and various forms of monster. The fourfold division was compatible with the idea of a lost primeval unity, the Judaeo-Christian Garden of Eden. ${ }^{12}$

Such diversification of geographica led men of science, theology and exploration during the Enlightenment to expect in the unknown fifth part of the world, 'human variety as on a scale of savagery to civilization, contingent on climate and environment'. ${ }^{13}$ This literature was fundamental for Bernard Smith's understanding of how European artists, explorers and settlers imagined and visualised the landscape and inhabitants of the South Pacific during the eighteenth and nineteenth centuries, and which as he discovered, still persisted in postwar England. Australia, it seemed, had retained its mythical status amongst educated Englishmen such as Anthony Blunt and Sir Kenneth Clark, even if it was for the sake of rarefied amusement. But as Edward Said later argued, 'Men have always divided the world up into regions having either real or imagined distinction from each other'. ${ }^{14}$

As Bernard Smith uncovered a plethora of drawings, paintings, objects and specimens of flora and fauna, much of which lay hidden in museums and collectors' cabinets since it had been deposited during the eighteenth and early nineteenth centuries, he realised how much the sheer variation of species would have stupefied both learned and lay people and led them

11 O.H.K. Spate, 'The Pacific: Home of Utopias', in Eugene Kamenka, ed., Utopias (Melbourne: Oxford University Press, 1987), 23.

12 David Bindman, Ape to Apollo: Aesthetics and the Idea of Race in the 18th Century (London: Reaktion Books and the Paul Mellon Centre for Studies in British Art, 2002), 17.

13 Ibid.

14 Edward Said, Orientalism (London: Penguin Books, 1978), 39. 
to believe they had 'gradually complete[d] the picture of the universe as a vast ordered chain of being'. The Antipodes had 'open[ed] a new road to the science of man', or, as Ernst Cassirer put it:

the motto, 'Back to Nature' [could] be heard everywhere, in inexhaustible variations. Descriptions of the customs of primitive peoples were eagerly snatched up; there was a mounting urge to acquire a wider view of primitive forms of life ... Diderot made a report of Bougainville on his trip to the South Seas his starting point for celebrating with lyrical exaggeration the simplicity, the innocence, and the happiness of primitive peoples. ${ }^{15}$

Shortly after commencing his research, Smith received an invitation to join a large project on the art of Cook's voyages. The New Zealand scholar Dr J.C. Beaglehole, who was working on an edition of Cook's Journals for the Hakluyt Society, wrote to him:

Very interesting to me as we have been paddling around in NZ with the idea of the European trained eye impacted upon by Polynesian appearance and I should welcome extremely a treatment of the subject by one who has really made a study of it as you have. Also I am looking forward to your impressions of all the Cook stuff. ${ }^{16}$

The 'Cook stuff' consisted of some 3,000 material objects, journals and descriptive works of art, much of which had rarely been seen. Bernard Smith later admitted that 'none of us had the faintest idea of the scale of the task involved ... [and it] determined much of my subsequent scholarly life ... [and] also directed my Warburg research'. ${ }^{17}$

This material, which Smith had to catalogue, was considered 'low art' - apart from finished oil paintings by the professionally trained artist William Hodges - and belonged to ethnographic studies and natural history. For Bernard Smith, however, the attraction to early colonial or exploration art was twofold: it bridged the trained scientific eye with visual descriptions often made in situ by trained naturalists or untrained artists, and, importantly, it showed the origins of contact, exchange and cultural convergence. While his research demanded a comprehensive analysis of history, from scientific and botanical discoveries to philosophies of identity, politics, social and power relations, it was the art of topography,

15 Ernst Cassirer, The Question of Jean Jacques Rousseau (Bloomington/London: Indiana University Press, 1963), 49.

16 J.C. Beaglehole to Bernard Smith, 6 April 1950, Bernard Smith Papers, NLA, Acc 10.088, Box 4.

17 Bernard Smith to Doug Munro, 6 April 2000 (copy provided to author by Doug Munro). 
botany and ethnography, or that which depicted the noble or ignoble natives that excited him. The intricate and superbly drawn flora and the crude realism or unsophisticated drawings and portraits of indigenous peoples provided a more accurate and comprehensive procession of discovery, and revealed the local agencies of encounter between nativism and imperialism, between 'the colonised and the colonisers'.

Moreover, Smith found this type of art far more valuable than 'high art' or the romantic landscapes and grand history paintings finished in the artist's studio for an elite audience such as the Royal Academy, where fashionable style was preferable to truth. 'Low art' provided information, and for Smith 'there was no embarrassment to look at [it]'. ${ }^{18}$ This statement discloses his working-class background and Marxist beliefs, in that art should possess a social consciousness or combine a utopian aesthetic within its cultural production. As he put it, Marxism gave him a 'dislike for any kind of elitist attitude to a subject'. ${ }^{19}$

An excellent example of 'low art' is the sketch titled 'First Contact', originally thought to be by Sir Joseph Banks but more recently identified as being drawn by a young Ra iatean native called Tupaia, who sailed on Cook's first voyage in $1768 .^{20}$ It is an extraordinary work of innocent vision and depicts the face of British imperialism as it engages with the exotic - a naval officer bartering a crayfish with a Māori. Indeed, it was this type of naive drawing that best encapsulates one of Bernard Smith's most important historical tropes, that of the 'revision of territorialism, possession and ownership as seen through the dramatic acquisition of the exotic as a potential commodity..$^{21}$

18 Bernard Smith, interviewed by Neville Meaney, 6 November 1986, NLA, Oral History Programme, TRC 2053/17.

19 Ibid.

20 Harold B. Carter identified Tupaia as the artist in April 1997 from a letter written by Banks in 1812 to Dawson Turner, a Fellow of the Royal Society. See Keith Vincent Smith, 'Tupaia's sketchbook', Electronic British Library Journal, 2005, www.bl.uk/eblj/2005articles/articles.html, in which he quotes Banks's letter: 'Tupaia the Indian who came with me from Otaheite Learnd to draw in a way not Quite unintelligible[.] The genius for Caricature which all wild people Possess Led him to Caricature me \& he drew me with a nail in my hand delivering it to an Indian who sold me a Lobster but with my other hand I had a firm fist on the Lobster determined not to Quit the nail till I had Livery and Seizin of the article purchased.'

21 Sheridan Palmer, Hegel's Owl: The Life of Bernard Smith (Sydney: Power Publications, 2016), 122. This chapter draws extensively upon this biography. 
But Bernard Smith did not intend to analyse Australia 'as a geographer might $\ldots$ in terms of physical structure and climate, nor yet purely in terms of literature and art, but something between the two. ${ }^{22}$ Synthesising complex ideas and finding interdisciplinary connections and overarching narratives reflected his pluralist methodology, but it also revealed his skill in locating interstices. The focus on art as a recording tool of the binary manifestations of science and nature, the empirical and the romantic, also repositioned the role of the artist as primary witness and descriptor of historical events and things that had never before been seen. This lifted the art of exploration out of its narrow confines towards a new visual plateau in which 'witness' art illuminated the root of contact with the exotic and unknown. It was an extraordinary lens through which the geopolitics of imperialism, identity and cultural convergence could be more thoroughly contextualised. Even James Cook and Joseph Banks had insisted that 'the drawings made on the voyages would provide a better idea of the matter under discussion than their own words'. ${ }^{23}$ The philosopher Emmanuel Levinas also believed that ' $[t]$ he judgement of history is set forth in the visible. Historical events are the visible par excellence; their truth is produced in evidence'. ${ }^{24}$ Between this descriptive 'low art' and literature on imperial exploration, Bernard Smith was able to conceptualise how the idea of a 'working man's paradise', or a new society in the great southern continent was envisaged.

One of Britain's most influential patrons and wealthy young 'experimental gentlemen', who helped determine the future of New Holland, was Joseph Banks. He accompanied Cook on his first voyage in 1768 and his advice that Terra Australis could become 'a food basket for both Great Britain's and Europe's immigrants, convicts and her "redundant poor" was heeded by the House of Commons in the late 1770s. ${ }^{25}$ It was pivotal to the colonising of New South Wales as well as relieving pressure on England's penitentiary problems and burgeoning population. As Smith noted, Australia:

22 Bernard Smith, 'The Artist's Vision of Australia', given as a talk on the BBC in 1950 and published in The Listener, 30 November 1950, 631-3, and later in The Antipodean Manifesto: Essays in Art and History (Melbourne: Oxford University Press, 1976), 159.

23 Bernard Smith, proposal to Yale University Press, 1978, Bernard Smith Papers, Mitchell Library, MSS 5202, add on 2039.

24 Emanuel Levinas, quoted in Peter Osborne, The Politics of Time: Modernity and Avant-Garde (London/New York: Verso, 1995), 123.

25 Alan Frost, 'The Planting of New South Wales: Sir Joseph Banks and the Creation of an Antipodean Europe', in R.E.R. Banks, B. Elliott, J.G. Hawkes, D. King-Hele and G.L. Lucas, eds, Sir Joseph Banks: A Global Perspective (Richmond: Royal Botanic Gardens Kew, 1994), 137. 
inherited neither craft traditions nor the Grand Style of Sir Joshua Reynolds. The convicts and the 'redundant poor,' who constituted the early Australian community had been dispossessed of their cultural traditions almost as completely as they had been dispossessed of their land and their citizenship by the legal code of eighteenth century England. No country in the history of the world has begun the history of its art under more unpromising circumstances than Australia. ${ }^{26}$

But the priorities of imperial possession and mercantile expansionism also simultaneously presented a paradox of freedom and imprisonment, material wealth and reformism, scientific progress and economic materialism. As the influential Joseph Banks oscillated 'between the world of science and the world of taste', he and his circle of dilettante gentlemen created a concept of Terra Australis as a potential destination for the grand tourist. This quest to satisfy an elite appetite for curiosities enhanced the Antipodes not only as an appendage of Empire but as a utopia inhabited by the noble savage, weird animals and strange vegetation, which, in the public's imagination, confirmed those ancient perceptions of the Antipodes as a large, primitive counterbalance to the civilised northern hemisphere.

As the Europeans and British sailed into the South Pacific, they were confronted by their own limitations and constructed the spectacular 'unknown ... in terms of the known'. ${ }^{27}$ This, as far as Bernard Smith was concerned, illustrated 'the insular British mind' and how it reacted 'to the vast ocean spaces' and 'free-love' arcadias of the South Sea islands, in particular the Society Islands and Tahiti. ${ }^{28}$ What it did achieve, however, was a new system of perception from which a transformative arts program developed in Britain and Europe. W.T.J. Mitchell has pointed out that '[j] ust as the landscape movement was at its height the islands of the South Pacific and the larger continental prize of Australia loomed to dislodge the Romantic pastoral'. ${ }^{29}$ The exotic lands of the New World and the sensual nature of its Oceanic people introduced a new language,

26 Bernard Smith, 'Australian Art and War', Bernard Smith Papers, NLA, MS 8680, Box 2/65.

27 Greg Dening, 'Ethnography on my Mind', in Bain Attwood, ed., Boundaries of the Past (Melbourne: History Institute, 1990), 15.

28 Bernard Smith, Imagining the Pacific: In the Wake of Cook's Voyages (Melbourne: Miegunyah Press, 1992), xi.

29 Bernard Smith, European Vision and the South Pacific: A Study in the History of Art and Ideas (Oxford: Clarendon Press, 1960), 4; W.J.T. Mitchell, 'Imperial Landscape', in Mitchell, ed., Landscape and Power (Chicago/London: University of Chicago Press, 1994), 18. 
both literary and pictorial, that helped change the nature of English art during the late eighteenth century away from classicism towards a poetic or mysterious sublime.

While exploration of the South Pacific may have initially romanticised the origins of European settlement in Australia, the anticipated utopia fell well short of being a working man's paradise. Instead, it became a colonial experiment in dispossession for the transported and the Indigenous inhabitants and a fatal attrition of native populations through murder and disease. What enabled Bernard Smith to analyse this period and its imperialist material so brilliantly was his acute sense of the 'unequal exchange' - typified by his meeting with Anthony Blunt - and his hostility to anything that subordinated ideas or relations of exchange. This yielded an understanding of power relations that gave his ideas and grasp of history real resonance, especially when he reached one of his most significant intellectual peaks during the height of the Cold War. Later in 1980, when he gave the Boyer lectures, The Spectre of Truganini, Smith drew upon the crime of dispossession that had occurred during the British invasion and colonisation of Australia, and the subsequent immolation of the Indigenous population. These brilliant essays on the locked cupboard of our history' revealed his sensitivity towards the injustice of conquest, whether historical or contemporary, and anything or anyone subverted by moral and ethical arrogance. ${ }^{30}$

Bernard Smith's two-year sojourn in England marked a major turning point in his career; it crystallised his scholarship and launched him into a school of international scholars, many of whom critically tested his intellectual credentials while also praising his ideas and achievements. For Bernard Smith, it confirmed the importance of measuring Australia against Europe, locating the intervals between reality and myth and synthesising the cultural and political strands that linked or locked these two countries together. As he said, 'I was looking for sources and the sources were northern European and still are'. ${ }^{31}$

30 Bernard Smith, The Spectre of Truganini (Sydney: Australian Broadcasting Commission, 1980), 10.

31 'Interview with Bernard Smith' by Rex Butler, in Butler, ed., Radical Revisionism: An Anthology of Writings on Australian Art (Brisbane: Institute of Modern Art, 2005), 76. 


\section{The quest for identity}

Later in his career, Bernard Smith gave a seminar paper titled 'On being Antipodean' in which he spoke of his 'identity paradox'. Identity was about the ontology of interactive relationships between people and place - to think of Europe was to think of the other. ${ }^{32}$ His self-perception as the singular 'I', a filius nullius dispossessed of his natural parents, had taught him humiliation and social inferiority - 'Whose ya father Ben', the school boys would taunt or, as he later admitted, 'a state ward can't expect much'. ${ }^{33}$ So embedded in Smith's identity was this notion of being different that he emotionally distanced himself from those who wielded authority. ${ }^{34}$ In a letter to his friend Vincent Buckley in 1984, he expanded on this: 'many illegitimate children who do not succumb to self-pity experience a kind of distancing from society. One sees oneself almost as a kind of witness figure'. ${ }^{35}$ This ability to stand apart and conscientiously monitor society would develop into a conceptual device with which to archive the Antipodes and map how the British constructed the Pacific as a place and shaped its possession and reception. He summed it up as 'I am thinking of distance, or more precisely distancing, as an intellectual tool both for aesthetic evaluation and for writing of history. ${ }^{36}$

Bernard Smith also spoke of how his research in England in the late 1940s had made him 'look back at his own intellectual origins' and cultural inheritance. Born in 1916, he experienced the after effects of the Great War, the hardships of the Depression and witnessed, from a distance, the full panorama of the Second World War. Like many who matured during the angry decades of the 1930s and 1940s, when fascism and the European crisis dramatically altered concepts of identity, national boundaries and political power, he moved towards the left and joined

32 See Peter Beilharz, Imagining the Antipodes: Culture, Theory and the Visual in the Work of Bernard Smith (Cambridge: Cambridge University Press, 1997), doi.org/10.1017/CBO9780511470202.

33 Bernard Smith, The Boy Adeodatus: The Portrait of a Lucky Young Bastard (Ringwood: Penguin Books, 1985), 267; Smith, conversation with the author.

34 Bernard Smith claimed he was never abandoned as a child; he lived with his mother for the first six months of his life and once fostered saw her daily until the age of two, after which she wrote regularly, with Bernard corresponding with her once he had learnt to write. He also met his biological father on several occasions as a small boy but, from an early age, believed he did not belong to anyone. See Bernard Smith's first volume of autobiography, The Boy Adeodatus, for an account of his life to 1940.

35 Bernard Smith to Vincent Buckley, 8 December 1984 (copy), Bernard Smith Papers, NLA, Acc. 10.088, Box 66 .

36 Smith, unpublished notes, Bernard Smith Papers, NLA, MS 8680, Box 7/55/155. 
the Communist Party. This was the only party that he believed was politically and ideologically capable of renovating society and rectifying the hierarchical machine that Australia had inherited.

Also at this time in Sydney, Smith met a group of European refugee artists and scholars who had fled Nazism; outsiders defined by the dispossession of their cultural heritage and homeland. Though they had belonged to some of the great intellectual and artistic institutions of Europe, Europe was now their Antipodes. Not only did these exiled scholars dramatically expand Bernard Smith's knowledge, but they taught him to think on a global scale; it was through them that he began to develop his concept of 'antipodal inversion' and how cultural traffic affected provincial identity and its relation to metropolitan centres. Moreover, the refugees were firsthand witnesses of Europe's barbaric decline. Where once during the eighteenth and nineteenth centuries its imperial hand had dominated the South Pacific, in the 1940s Europe's and Britain's power lay dispersed and 'the disinherited' were the 'driving force for a revolutionary reconstruction of society'. ${ }^{37}$ It made Smith look at what had been brought to Australia, what had been absorbed, transformed or rejected or, as he retrospectively put it:

I was trying to define the business of what it is to be Australian, that is I was looking for what is typically Australian. But the only way you could logically define this, I thought, was to find out what is European, to distinguish what is European from what is Australian. ${ }^{38}$

For Bernard Smith, culture was a historical process and a man-made construction. The Pacific historian and ethnographer Greg Dening similarly believed that 'Culture' was an 'analytic concept ... of all human behaviour considered as expression and communication. Culture is an observer's construct'. ${ }^{39}$ Spatial and temporal distance was inherent in the observer's method, and Smith used it to identify intellectual and cultural patterns and to clarify and shape his discourse. It is why Dening wrote of Smith that he 'made us look at our own marginality in a positive way. Be Antipodeans, he told us'. ${ }^{40}$

37 H.G. Wells, Experiment in Autobiography (Harmondsworth: Penguin Books, 1934), 206-7.

38 Bernard Smith, interview with Hazel de Berg, NLA, Oral History Programme, TRC2053-17, Tape 1 (page 43 of typescript).

39 Greg Dening, 'Disembodied Artifacts: Edward Said's Culture and Imperialism', Scripsi, 9:1 (1993), 80.

40 Greg Dening, Readings/Writings (Melbourne: Melbourne University Press, 1998), 142. 
If Smith's concern was how Australia emerged from its colonial cradle and arrived at its own distinctive modern position, this also coincided with his own personal quest for identity as he distanced himself from his past. For some, illegitimacy fosters a deep and lasting sense of invisibility and of never belonging, and certainly Smith had experienced this during his childhood: 'No, he is not one of us', he heard his foster sister Bertha tell a stranger. But he was also born with a ferocious determination to escape from the institutional constraints of his orphaned status and rise above his humble beginnings. In Place, Taste and Tradition, he wrote that '[a] national tradition arises from a people as they struggle with their social and geographical environment' - one could think that here he was reflecting on his own struggle to leave his social periphery. ${ }^{41}$

In his research leading up to his magnum opus, European Vision and the South Pacific (1960), Smith captured an important factor affecting new settlers as they came to terms with the country's unique qualities, qualities that he had himself experienced as a young primary school teacher when he worked in a remote part of rural New South Wales:

For Australian nature was not merely something to be seen, but something to be revealed, something hidden from vulgar eyes and still unknown. The mystery of the bush could inspire not only fear but also hope ... and the hopeful and melancholic conventions fused into a complex unity capable of reflecting the finest shades of experience and emotion. They are therefore landmarks in the emotional maturity ... [of] Australian identity. ${ }^{42}$

Hope was the great mover of utopian ideas, and it kept Smith focused on his future. It was also central to Marxist thought.

By the late nineteenth century, after a new merchant capitalism emerged based upon the wealth of the gold rush, Australians began to assert themselves more confidently. This was evident in art, literature and architecture as well as the rapid growth of cities - the staging of the great International Exhibitions in Sydney, Melbourne and Adelaide, and the impressionistic paintings of a new national vision by Tom Roberts, Arthur Streeton and Charles Conder. By the early and mid-twentieth century,

41 Bernard Smith, Place, Taste and Tradition: A Study of Australian Art since 1788 (Sydney: Ure Smith, 1945), 30.

42 Bernard Smith, 'The Interpretation of Nature during the Nineteenth Century', BA Honours thesis (Department of English, University of Sydney, 1952), copy in Bernard Smith Papers, NLA, MS 8680, Box 3/20/21, 23 and 78 . 
artists such as Margaret Preston, Russell Drysdale, Sidney Nolan, Arthur Boyd and Noel Counihan and the writers Miles Franklin, Vance and Nettie Palmer, Frank Dalby Davidson and Brian Penton, to name a few, were constructing an Australian idiom with even greater assurance. But this vigorous Antipodean character began to wane again after the Second World War as dominant metropolitan cultures altered Australian cultural values.

Others have noted that Bernard Smith's interpretations of Australian art and identity were consistently based around 'the circularity between Europe and Australia', and never on a distinctive entity in and by itself. Yet this was precisely because of the Eurocentric cultural inheritance that had been implanted with British possession in 1788, and that continued well into the twentieth century. It was what made Australians 'refer back' in order to 'mediate influences' or 'wilfully disrupt' received styles and reposition themselves within their own locality. ${ }^{43}$ As he said, 'Even if the past is another country the historian has to find a way to get there'. For a cultural historian like himself, that route was through the dominant cultures of Europe and Britain. ${ }^{44}$

When Smith first arrived in England in 1948, he was concerned with this notion of identity and cultural revision. By the end of his two years there, and with extensive travels through Europe, he had developed a real sense of the cultural past and its global present, though he could never have stayed on in England nor felt comfortable in its class-based society - even though he had married a middle-class Englishwoman in Sydney in 1941. Bernard Smith was resolutely and defiantly Australian and, as he discovered, there simply was not enough interest in the Antipodes as a historical or modern cultural entity. Geographical distance and British principles of exclusion still hampered contemporary Australia almost as much as it had 150 years earlier. In a letter to his mother, he assured her he would not be staying on in England as he felt he could do much more important work back home.

Before leaving London in late 1950, Smith gave several broadcast talks at the British Broadcasting Corporation (BBC) on 'Australian Landscape Painting' and 'The Artist's Vision of Australia'. From the discovery by Cook

43 Geoffrey Batchen, in Ian Burn, Dialogue: Writings in Art History (Sydney: Allen \& Unwin, 1991), xviii.

44 Bernard Smith, notes for review of T.J. Clark's Farewell to an Idea, July 1999, Bernard Smith Papers, NLA, MS 8680, Box 8/57/176. 
and the importance of Sir Joseph Banks and Charles Darwin, Bernard led the listener through the unique qualities of the Australian landscape and how it created for artists a distinct way of seeing and a unique style of painting. From the colonial, picturesque, romantic and impressionist genres to the 'psychic centre' of the great outback, he finally arrived at Russell Drysdale who, he said, painted the landscape in its own terms of reference, as though he was 'half in love and half in fear of his subject ... because the Australian landscape is ... a wilful capricious thing, half-wild, half-tame, half-myth and half reality. ${ }^{45}$

\section{The pursuit of cultural autonomy}

After returning to Sydney in 1951, Smith became frustrated by the impact that prevailing American and British cultural forces were having on Australian art, and he was determined that an Antipodean cultural identity should be more internationally acknowledged. Australians viewed the world through their entrenched nostalgic attachment to Great Britain and this had to be replaced by 'an Australian way of looking'. Moreover, the western world's new watchdog, America, was using its invasive cultural power to assert its metropolitan monopoly in Europe and Australia and, according to Smith, this was twentieth-century cultural imperialism.

The historian Robin Winks once observed that a scholar's subject matter or academic discipline usually holds 'an autobiographical meaning, in that one is often attracted to a discipline that appears to reflect the world as one understands it, rather than using the discipline to order the world'. ${ }^{46}$ Bernard Smith used art and culture not only to understand 'the sociology of colonisation' and its relations of exchange but as a mirror for addressing his own personal 'position and position taking. ${ }^{47}$ One extraordinary construction for identity and cultural difference that he masterminded was the Antipodeans exhibition and its Manifesto in 1959.

As its originator and convener, Smith used the idea of myth-making to illuminate Australia's cultural autonomy and proclaim its distinctive originality; as he put it, "We live in a young society still making its myths. The emergence of myth is a continuous social activity. In the growth and

45 Bernard Smith, 'Sir Russell Drysdale (1912-1981): A Memoir', Art Monthly, 110 (1998), 28.

46 Robin W. Winks, The Imperial Revolution: Yesterday and Tomorrow (New York: Oxford University Press, 1994), 8-9.

47 Bernard Smith, interview with author, 7 June 2001. 
transformation of its myths a society achieves its own sense of identity'. ${ }^{48}$ But with politics never far from his mind, it was also an agenda for his concerns about regionalism, contemporary cultural imperialism and the Cold War.

Ever since first proposing the idea to Sir Kenneth Clark in London in 1949, Bernard Smith had been keen to mount an exhibition showcasing the best of contemporary Australian figurative art, with the aim of touring it nationally and internationally. The plan was reactivated in 1957, when he heard the Melbourne architect Robin Boyd deliver a lecture on Australia's de-culturalisation and the 'featurist' and 'Austerica' banality of its urban design and architecture. He wrote excitedly to Boyd:

I cannot tell you how much I admired and enjoyed your lecture ... I am right behind you - but can anything really be done about it? ... I should dearly love to think that one or two of our artists and architects were standing up squarely on their own feet and thinking out their own problems before an Australian and a world audience. Of course the waters of nationalism have always been treacherous ones to fish in - but at least they're deep.

As the letter shows, the genesis of the 'Antipodeans' had evolved:

What is needed is a small compact group of artists (architects, painters, perhaps a sculptor), about 6 or 7 would be enough with a common purpose ... one thinks of The Impressionists, de Stijl, The Pre-Raphaelite Brotherhood. ... Better to make history than write about it. What is needed is a brotherhood of some kind ... with a colourful title ... The artists I can think of ... who would qualify for what I have in mind are Sid Nolan, Arthur Boyd, John Brack. ... If some sort of Antipodean Brotherhood did somehow crawl upsidedownedly into existence its birth would have to be veiled in mysteries ... I can assure you I rarely write letters like this - but this is what you have brought me to ... Meanwhile my congratulations on your magisterial stand against the ... hands of Austerica. ${ }^{49}$

Art, Smith insisted, had to communicate as 'a recognisable shape, a meaningful symbol', and a reflection of society, and he used the Antipodeans exhibition as a platform to convert artists and audiences away

48 The Antipodean Manifesto, first published as a foreword to the Antipodeans exhibition held at the Victorian Artists' Society, East Melbourne, August 1959.

49 Bernard Smith to Robin Boyd, 22 September 1957 (copy), Bernard Smith Papers, NLA, MS 8680; these papers have recently been deposited in the NLA and are awaiting accessioning. 
from the 'vacuous geometric patterning' of international abstraction, a style that emanated from the dominant New York School of abstract expressionism and the 'canonical dominance of Clement Greenberg's post-painterly abstraction'..$^{50}$ Bernard Smith had first witnessed this new art form at the 1950 Venice Biennale where Jackson Pollock's dribble technique or, as Bernard described it, the 'glamorous wallpaper of his own alienation' was on show. ${ }^{51} \mathrm{He}$ also had information that major American exhibitions, which had been touring Europe since the beginning of the Cold War, were funded by the CIA and New York's Museum of Modern Art (MoMA), which further intensified his hostility towards America's postwar cultural hegemony.

Bernard Smith qualified cultural imperialism as 'a study in inequality', and therefore 'what is vital and native to our tradition' needed to be protected. This was not xenophobic nationalism but, as Peter Beilharz has suggested, a more cryptic, hybrid form of nativism..$^{52}$ Australian artists, Smith wrote, had to 'battle for survival in the post-war years against powerful and at times overwhelming cosmopolitan tendencies, at times stimulating and vitalizing, at times devitalizing. ${ }^{53}$ With his sight fixed on Australia as it intersected with metropolitan cultural powers, Bernard chose seven artists who were 'distinctively Australian, without being self-consciously nationalistic'. ${ }^{54}$ These were John Brack, Charles Blackman, Arthur and David Boyd, John Perceval, Clifton Pugh and the Sydney painter Robert Dickerson. To avoid being tagged nationalistic, the group, driven by Bernard's preferences, chose the word 'Antipodeans'. As he explained:

Europeans have used [the term] in connection with this part of the world ever since the Greeks and there is no reason at all why we should sneer at it ... no reason why painters ... should not be able to find something worth saying both to their community and to the world at large. ${ }^{55}$

50 Gary Willis, conversation with the author, 2015.

51 Bernard Smith, A Pavanne for Another Time (Melbourne: Macmillan, 2002), 444.

52 'A day with Bernard Smith', La Trobe University Thesis Eleven symposium, 23 April 2003.

53 Smith, notes for a speech given at the annual dinner of the Fellowship of Australian Writers, 1 September 1959, Bernard Smith Papers, NLA, MS 8680, Box 20/24. Bernard later published a significantly revised version of events with 'The Truth about the Antipodeans' published in The Death of the Artist as Hero: Essays in History and Culture (Melbourne: Oxford University Press, 1988).

54 Bernard Smith to Sidney Nolan, 1 February 1960 (copy), Bernard Smith Papers, NLA, MS 8680.

55 Ibid. 
He also suggested to Charles Blackman, the artist who designed the Antipodean Exhibition poster, that he should look at the primitive Antipode creatures illustrated in the 1493 medieval Nuremburg Chronicle, a copy of which was held in the Melbourne public library.
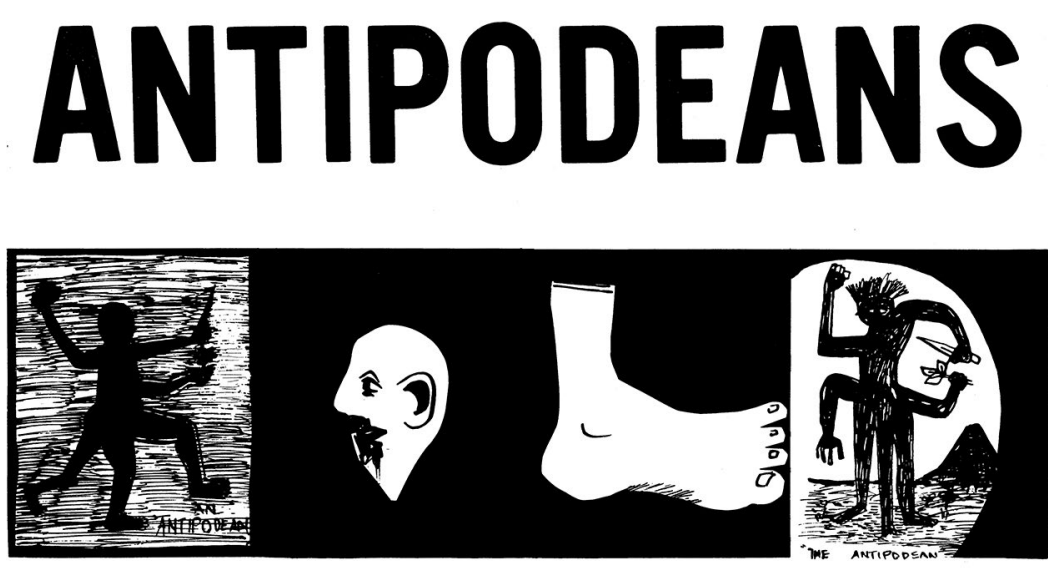

\section{4th AUGUST to 15th AUGUST}

VICTORIAN ARTISTS SOCIETY

CHARLES BLACKMAN ARTHUR BOYD DAVID BOYD JOHN BRACK BOB DICKERSON JOHN PERCEVAL CLIFTON PUGH. BERNARD SMTTH Antipodeans exhibition poster, 1959

Source: Private collection.

By refashioning the mythic past with the political present, Bernard Smith's promotion of antipodeanism declared a distinctive aesthetic while simultaneously asserting a national autonomy. As he said, '[i]t is natural that we should see and experience nature differently in some degree from artists of the northern hemisphere'. ${ }^{56}$ Moeover, by establishing a regionalist, figurative style - Smith preferred calling it 'being oneself [or] standing on one's feet' - in opposition to international abstraction, Australian artists might have a chance of being noticed. Aesthetic individualism was important, but it was also about challenging the political giants and their cultural supremacy - though at the time he did not present it to the artists as such. In retrospect, he explained that the exhibition and Manifesto were 'not at bottom an attack on abstract art; it [wa]s an attack on the

56 'The Antipodean Manifesto', published in The Antipodean Manifesto: Essays in Art and History (Melbourne: Oxford University Press, 1976), 197. 
policy of the State Department of the USA to use abstract art as a political instrument in opposition to the Soviet Union's use of socialist realism as a political instrument'. ${ }^{57}$ Given the Cold War tensions in the late 1950s, Bernard Smith's obsession with power relations and dominant cultures was understandable, but it also reflected his hostility to anything that 'subordinated ideas or relations of exchange'. The price of survival had always interested him, whether that of the convict, the destitute, the state ward, Aborigines or the marginalised individual or artist - it resonated deeply with his outsider self.

The Antipodeans exhibition was an enormous success and consolidated the seven artists' professional reputations, yet it also became one of the most divisive events in the history of the Australian art world. Not only had it politicised art but it reignited antagonism between Melbourne and Sydney artists and provoked rivalry between the 'abs' and the 'figs' - Smith was accused of derailing abstraction and tying figurative art to the tracks and holding it ransom. Others like Helen Brack objected to the 'genius' factor that positioned one artist above another or, more specifically, one group above all others. ${ }^{58}$ In this, Bernard Smith's Marxism and egalitarian beliefs had faltered and his selection of the artists was seen as elitist; his own defence was that he had chosen them for their political neutrality and distinctive Antipodean content. In Barbara Blackman's view, however, the exhibition was 'an irrefutable landmark in Australian art':

Where tradition is wanting, certain prejudices and preconceptions may also be lacking. The Antipodeans made their gesture from necessity and out of direct experience and so have helped to shape the present particular contours of our art, a distinctive and virile growth alongside the modern art of other countries. ${ }^{59}$

\section{The periphery versus the centre}

While Bernard Smith did all he could to get the Antipodeans exhibition to London, he was stymied by the local antagonism of artists towards him, as well as by the British establishment and its cultural elites exemplified by Sir Kenneth Clark and Bryan Robertson, the director of the Whitechapel

57 Bernard Smith, cited in Beilharz, Imagining the Antipodes, 117.

58 I am grateful to Helen Brack, who was closely associated with the entire development of the Antipodeans exhibition, for discussing Bernard's authority in determining the exhibition and its controversial Manifesto.

59 Barbara Blackman, 'The Antipodean Affair', Art and Australia, 5:4 (1968), 607-16. 
Gallery in London. Robertson had been developing a large exhibition of Australia's best contemporary artists, including the Antipodeans, and this was held in 1961 at the Whitechapel Gallery. To add insult to injury, Robertson bypassed Smith as a major critic of Australian art and invited the young Sydney architecture student and flamboyant art critic Robert Hughes to write the catalogue essay for the exhibition.

In the introductory essays, Clark and Robertson stressed that Australian culture had been moulded by isolation and the country was seen as a major food bowl producer in which the 'redundant poor' had been replaced by 'sun bronzed sheep farmers' ${ }^{60}$ The stigma of the 'working man's paradise' remained firmly rooted in the European psyche and the spinning of the myth was too irresistible for these cultured Englishmen, whose attitudes were diametrically opposed to Smith's. Robertson's colourful rhetoric emphasised the country's vast landscapes, immense distances and a heightened sense of isolation:

A friction in the air itself finds expression in the edge and bite which underlies [its] art. A fierce, tough, often rather slangy imagery is invariably described in the most tender and loving manner ... [but] the imagery itself, cut off from our European environment, is highly inventive and has one unifying factor: an unremitting sense of the drama of the isolated moment. ${ }^{61}$

He also claimed that '[a] nation based on an idea rather than on blood needs some transcendent image to reveal itself'. In a veiled reference to Smith, Robertson wrote:

Power politics have made nationalism a dirty word ... Australian artists ... are at once passionately interested in what is Australian art and highly suspicious of the answer. At the same time, these problems do not concern the painters as much as critics and interpreters for who the painters feel mostly a proper and essential distrust. ${ }^{62}$

Hughes also parodied Smith, 'some things I am told, can only be seen clearly from a considerable distance' and that 'exoticism depends on where you stand'. ${ }^{63}$ With his superb cast of phrase, Hughes continued, 'The first convict settlement was made here [Australia] in 1788. In the

60 Bryan Robertson, Recent Australian Painting (Whitechapel Art Gallery, exhibition catalogue, 1961).

61 Ibid.

62 Ibid.

63 Robert Hughes, in ibid., 13. 
next few years, a cultural transplantation took place. But though you can ship works of art, you cannot put a climate of thought in a crate'. As he proceeded to decipher the past, uproot its traditions and uncover Bernard Smith's political mask, referring to him as a 'critic' who had 'evolved' an Australian mythology, Hughes took aim:

Recently an 'opposition group' was formed in Melbourne under the leadership of the distinguished art historian Bernard Smith. His programmic intent was clear. Australia he argued lacks a tradition of art but possesses strong social traditions. It has acquired its own myths, heroes and white man's folklore. If the artist, then, is to function as an effective social unit his art must reflect this and draw its inspiration from it ... The Antipodean notion of an image seems to concern a pressure point for a number of beliefs ... which need have nothing to do with aesthetic sensation or the existence of the object itself. It is an art of association. Under this aspect, an image is the firing pin and not the grenade. ${ }^{64}$

Smith, however, was not to be marginalised and took his revenge.

In the John Murtagh Macrossan Memorial Lectures, which Bernard Smith titled 'The Myth of Isolation' and 'The Rebirth of Australian Painting' given at the University of Queensland in $1961,{ }^{65}$ he asserted that while there was 'some core truth at the heart of any myth', Australia had never suffered from cultural isolation, from neither Europe's Renaissance nor its modernist movement. ${ }^{66}$ As a young pastoral society, its cultural identity had been formed upon a Eurocentric philosophical and cultural inheritance, and what had been brought to the colony was adapted, modified or changed by the geographic, climatic and developing social conditions, not formed under isolation. During the 1950s and 1960s, as in the late 1940s, the reception of Australians in London was usually simplistic, being seen more often as the poor, uncultured cousins from behind the black stump. ${ }^{67}$ The London critic John Douglas Pringle, who had lived and worked in Sydney, understood how the British tended to misread Australia as a distant, inhospitable land of mythological proportions; he began his review of the Whitechapel exhibition tongue in cheek:

64 Ibid., 19-20.

65 The John Murtagh Macrossan lectures were published as Australian Painting Today (Brisbane: University of Queensland Press, 1962).

66 Smith, 'The Myth of Isolation', 16.

67 Sheridan Palmer, 'The Lone Antipodean - Bernard Smith's Post-War Modernism', Eyeline Contemporary Visual Arts Magazine (Brisbane), 78/79 (2013), 55. 
Many people in this country must imagine that contemporary Australian painting is a rather exotic art form discovered by Sidney Nolan in a cave near Alice Springs, round about the year 1940, and since handed on under oath of secrecy sealed in wallaby blood - to Albert Tucker and Arthur Boyd. ${ }^{68}$

While Australia's cultural character had been carved out from its dominant European beginnings, Bernard Smith stressed that a culture on the periphery was able to develop in more vital ways precisely because it was less hampered by the ever prevalent 'graveyard of memory' or the heavy hand of European cultural traditions evident in major northern centres such as Paris, London and New York. Australian cultural identity was not inferior or forged through provincial isolation, but lay in its democratic difference.

The Macrossan lectures, though reaching only a small audience, were a brilliant riposte to those British who still clung to the notion of Australia as a colonial appendage. Bernard Smith also refuted their image of Australian art as some exotic, crude imitation of Europe's great painters, and accused them of having 'disastrously misrepresented modern Australian artists' as 'white noble savages'. These English values, Smith felt, were deeply entrenched and maintained by their imperial distance and cultural elitism.

Bernard Smith's willingness to 'stand alone' and question cultural hegemony gave him a reputation as a critical interventionist and a vitally important intellectual at a time when Australia's modern cultural identity was in a major developmental phase. His Antipodean discourse, though seen by some as inhibiting, was critical to artists as they aesthetically defined themselves during the Cold War and in an increasingly globalised world. Later he wrote, 'Distance is our longue durée, the near constant factor in our history, that does so much to transform our art - and if we are creative and intelligent we can put it to our advantage' ${ }^{69}$

68 John Douglas Pringle, 'The Australian Painter', Observer (London), 4 June 1961. Pringle was a well-informed and brilliant editor who lived and worked in Australia during the 1950s and 1960s as editor of the Sydney Morning Herald.

69 Bernard Smith, opening address at the S.H. Ervin Gallery, 16 April 1984, for the exhibition 'Aspects of Australian Figurative Painting 1942-1962: Dreams, Fears and Desires', Bernard Smith Papers, NLA, MS 8680. 


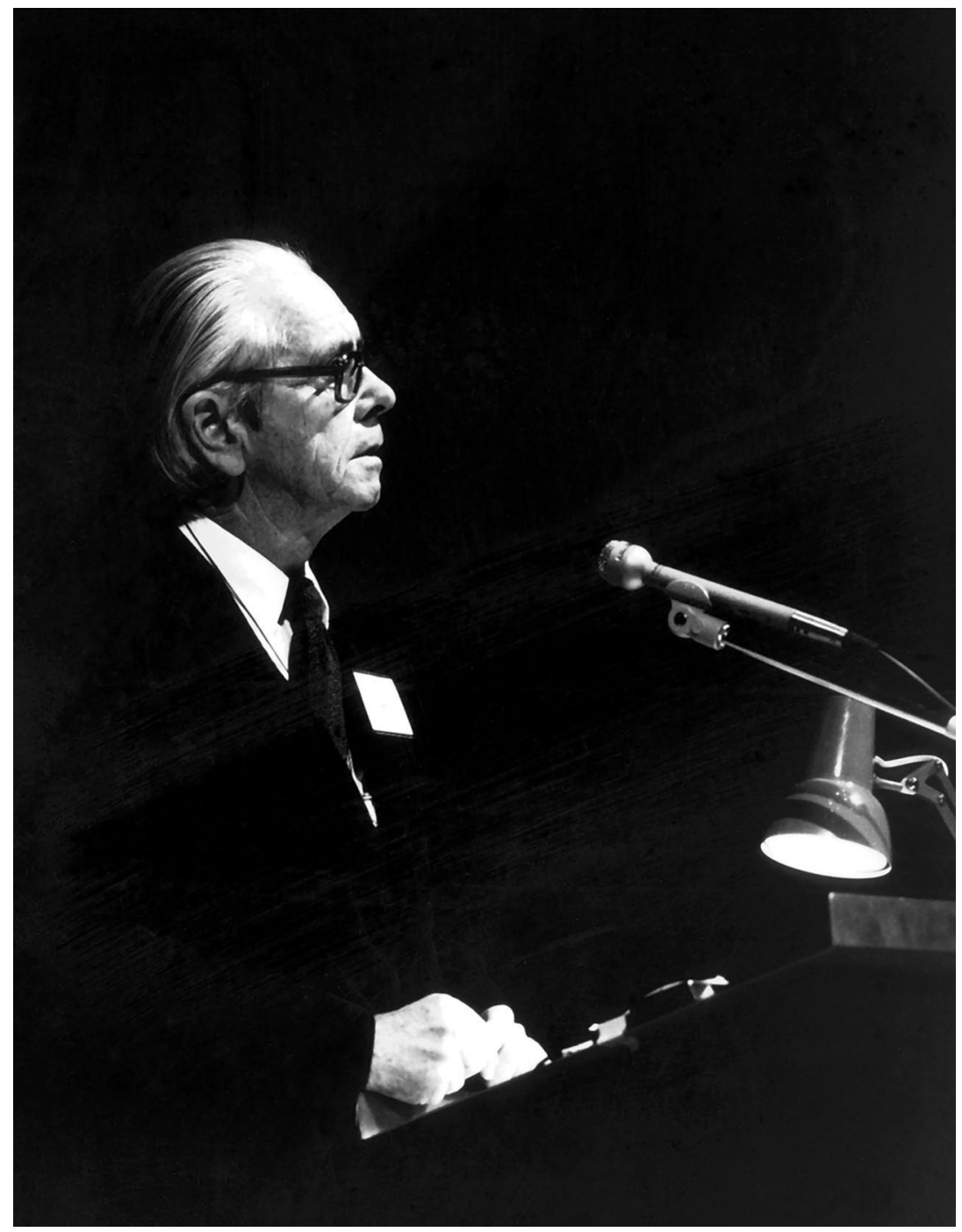

Bernard Smith, 1978

Source: Bernard Smith Papers, National Library of Australia (photographer unknown).

For much of the remaining twentieth century, Smith's polemics on cultural identity and traditional inheritances set a benchmark for Australian critics and art historians, but his influence extended well beyond them to other disciplines such as anthropology, Pacific and cross-cultural studies, and artists working nationally and internationally. If European Vision and the South Pacific had established him as a major revisionist - one art critic considered it 'one of those mind-changing works which truly extend not 
just knowledge but the frame-work in which to place that knowledge ${ }^{70}$ - then his epic vision of Australia's cultural condition and his theories of contact, exchange and identity, together with his ability to steer a critical course through vast historical terrains, mark him as one of this country's most brilliant and pioneering intellectuals.

Indeed, European Vision and the South Pacific predated Edward Said's Orientalism (1978) by almost 20 years. For Smith, Australian artists mattered and he was emphatic that they deserved to be recognised internationally. On this he was prepared to stake his professional reputation and fight at the barricades of modernism and challenge the metropolitan systems of cultural elitism. Even when his peers and intellectual children considered him anachronistic, he remained a vital figure in Australia's cultural modernisation.

As a Marxist utopian, Bernard Smith believed in the future and found generational change exciting; it helped him absorb the zeitgeist of the day, which in turn helped him define his arguments and redefine his identity amongst the next generation of Australian art and cultural historians. In this, he was determined to maintain a visible and intellectual presence well into his old age, even if it meant being overtly provocative. In 2002, aged 86, Smith posed naked for the artist Carmel O'Connor's Archibald Prize portrait. The reclining, unclothed image of the father of Australian art history was deliberately designed to shake up bourgeois complacency, challenge the uncritical Australian culture and address the demise of figurative art. Smith insisted that his pose be constructed on the classical Roman sculpture known as the Barbarini Faun, or The Sleeping Satyr, which enabled him to incorporate complex connections and mythical metaphors. The faun or satyr was considered as representing the mythic messenger of man's origins, and Bernard Smith had always been interested in origins. ${ }^{71}$ Moreover, the portrait was a final 'identity performance' with the aged and eminent art historian unashamedly parading as the emperor with no clothes and imparting his lesson aimed at the crisis of identity in the postmodern age.

70 Charles Nodrum, 'Bernard Smith and the Formalesque', unpublished article, courtesy of Charles Nodrum.

71 Friedrich Nietzsche, The Birth of Tragedy; and, the Genealogy of Morals (New York: Doubleday Anchor Books, 1956), 52. 
What was important to Bernard Smith was to keep the dialogue open and arguments on traditional and contemporary art moving. He saw his role as reinvigorating the cultural debate, and in this his conscientious criticism was inescapable, even when attempts to dislodge him from his prominent position in Australian art history were made. So influential was his published work and extensive criticism that other art historians found it impossible not to use it as their matrix upon which to formulate their own theories of centre and periphery or metropolitan power and provincialism. Smith's critiques of cultural hegemony were adopted, interrogated and reconstructed by younger art historians and sociologists during the latter part of the twentieth century, which repositioned him at the core of a new plateau of revisionism and discourse on contemporary identity. ${ }^{72}$ In particular, the neo-Marxists Ian Burn and Terry Smith appropriated the issue of provincialism in the 1970s and 1980s, and in the early 1980s the young art critic Paul Taylor and his colleague Paul Foss 'channelled' Bernard Smith's early theories of cultural imperialism and the importance, or unimportance, of locality. As the Australian art world's eminence grise, Bernard Smith was the benchmark and, as the art historian Rex Butler more recently claimed, we should continue to 'turn to the true precursor of revisionism' and the originator of 'the great Australian idea' of antipodal inversion or 'reversal to the rest of the world. ${ }^{73}$

Bernard Smith questioned the Antipodean psyche and gave it significant cultural form as well as proclaiming its place in a globalised world. His intellectual and aesthetic landscape was vast, Antipodean, Eurocentric and universal, and he traversed these terrains confidently. It was cultural evolution that propelled his curiosity, for through culture it was possible to understand the socioeconomic and political mechanisms attached to power, and these were vital to his self-actualisation; it is what drove his desire to legitimate place and liberate the marginalised. Even when he used his own symbolic image of the outsider in order to understand hegemonic relations, class differences and inequality, it was ultimately situated within the larger disciplines of philosophical ideas on origins,

72 Some major texts indebted to Bernard Smith's historiography include Terry Smith, 'The Provincialism Problem', Artforum, 12:6 (1974), 49-52; Ian Burn, Nigel Lendon, Charles Mereweather and Ann Stephen, The Necessity of Australian Art (Sydney: Power Publications, University of Sydney, 1988); Heather Barker and Charles Green, 'No More Provincialism: Art \& Text', emaj, 5 (2010), www.melbourneartjournal.unimelb.edu.au/E-MAJ.

73 Butler, Radical Revisionism, 12. 
identity and identification; indeed, he believed we must classify in order to understand the historical agencies and shifting paradigms that have shaped us.

If Bernard Smith used myths to frame his discourse on antipodeanism and unravel the historical, scientific, cultural and political forces that moulded Australian art and its modern cultural identity, he was equally aware that utopias were an ideological construct of the emigrant and the intellectual voyager, and both were fundamental to historical processes and human progress. As he said, 'I am a communist, in so much as a utopian communist, I believe in the future-the hope is in the waiting..$^{74}$ In other words, he had never shifted from his Marxist humanism and his belief that a better future was possible for the world.

74 Bernard Smith, conversation with the author, 2011. 
This text is taken from Clio's Lives: Biographies and Autobiographies of Historians, edited by Doug Munro and John G. Reid, published 2017 by ANU Press, The Australian National University, Canberra, Australia.

dx.doi.org/10.22459/CL.10.2017.09 